\title{
Earth system sciences and permaculture: contributions to environmental education
}

\author{
Elza C. Wenceslau', Josel M. Piranha ${ }^{2}$ \\ 1 - Postgraduate Program of Teaching and History of Earth Sciences, P0 Box 6152, 13083-855 Campinas, SP, Brazll. E-malls: ellza.cw@hotmall.com \\ 2 - Reference Center in Earth System Science - CReCist, Department of Chemistry and Environmental Sciences, Institute of Biosciences, Humanties and Exact \\ Sciencees,(IBILCE), São Paulo State Unversity (UneSP), 2265 Cristóvāo Colombo st., São José do Rio Preto, SP, Brazll. E-malls: Josell.unesp@gmall.com
}

Abstract: In view of the environmental crisis that plagues the world today, resulting from the dissociation of man and environment and the low effectiveness of educational policies, especially regarding Environmental Education, the need for a paradigm shift is evident, transforming the way of teaching and thinking about Environmental Education. In that respect, it is believed that the concepts advocated by Earth System Science, applied to Permaculture, can contribute to the development of a more humanistic and respectful culture, besides providing man with a new outlook on the environment. Thus, the present work exposes the foundations of these two theoretical references (Earth System Science and Permaculture), aiming to contribute to the reform in thought, and allowing the teaching and learning process in Environmental Education to be more effective and consistent. While Earth System Science allow the systemic understanding of the planet as well as the complex relationships between its various constituents, Permaculture seeks a harmonious coexistence of man and the environment. They value, in an analogous way, the interrelations between the constituents of the system, revealing alternatives that enable changes in the way the natural environment is occupied, making it more sustainable and raising consciousness.

\section{Manuscript:}

Received: Quadrennial Conference of the International Geoscience Education Organization Accepted: 14/01/2018

Citation: Wenceslau E.C., Piranha E.C. 2018. Earth System Science and permaculture: contributions to environmental education. Terræ Didatica, 14(4):363-368. URL: http://www.ige. unicamp.br/terraedidatica/.

Keywords: Permaculture, Earth System Sciences, Environmental Education, Geosciences Education.

Thematic line: Environmental Education, Sustainability Education and Geoethics

\section{Introduction}

Considering the low effectiveness of currently developed actions regarding Environmental Education (EE) in Brazilian schools, which is reflected in the progressive aggravation of socio-environmental crises and in the indifference with which students face their daily effects, the potentialities of Earth System Sciences and Permaculture for the formation of values of citizenship and in the promotion of a sustainability culture stand out.

The understanding of the systemic condition and interdependence of Life on Earth invites learners to see themselves as components, dependent and, at the same time, co-responsible for the care of natural resources. Permaculture, in turn, seeks a harmonious and conscious interaction between man and environment, using differentiated approaches to land use, agriculture, livestock, construction engineering, and proposing a responsible and enduring coexistence of man with the environment.

In this context, it is hoped that the approach presented here will lead and contribute to a reflec- tion that helps understand how and to what extent the articulation of the knowledge of Earth System Science and Permaculture can contribute to a more effective, consistent and coherent EE. Therefore, a reconnection of man with the environment is sought, as well as the emergence of a sense of belonging, essential for the behavioral changes that are becoming urgent.

\section{Development}

\subsection{The global crisis and the need of a new humanitarian formation.}

Planet Earth is extremely dynamic, naturally transforming itself since its formation, approximately 4.56 billion years ago (Grotzinger \& Jordan 2013). None of its constituents is static, the terrestrial "floor", the crust, is constantly formed and recycled in internal and external interactions by tectonic plate systems and by climate, which modify the surface environment. However, with 
the development of human species and its irrational and rapid dissociation from the natural environment, the planet has been transformed dramatically by anthropic action.

We must think about what is happening on the planet today. News of violent actions of man towards the environment are frequent, without the consequences even being considered. The predatory view that the human species maintains about the environment poses problems on a global scale. In view of these complications, environmental issues are increasingly present in the media. Ratto et al. (2017) point that out:

Faced with so much environmental devastation, global warming, tons of garbage produced by us every day, and so many other examples [...], we realize that concern for the environment has become a central issue. It is no wonder that we see this concern erupt in schools, in Non-Governmental Organizations, in supermarket networks, in banks and, most strongly, in the media in general.

In view of this, it is difficult not to evoke the notion of humanity with regard to the sense of benevolence of man towards man. The importance and urgency of not losing sight of the inseparable relationship Man-Environment is also evident. Compiani (2002) states that the socio-environmental crisis forces us to seek an understanding of the interdependence between society and nature. According to Ratto et al. (2017, p. 1026):

Perhaps it is from this awareness of the implication, from this inseparability of Earth, for recognizing ourselves as an inexorable part of nature itself, that some real power of transformation emerges.

Still in this sense, Piranha (2006, p. 4) affirms that Man "by conceiving himself worldly, can also see himself equally responsible for deconstructing models that he recognizes as improper.

Capra (1996) argues that the more we analyze our contemporary problems, the more difficult it is to think of them as isolated and independently occurring events, emphasizing that they are, therefore, systemic problems. To solve this problem, a radical change of paradigms, values and behaviors is necessary, both in the field of sciences and in society in general (Capra 1996).

In this sense, EE becomes a necessary part in the search for those fundamental changes in the future of life on this planet. EE is defined in Article 1 of the National Environmental Education Policy (Brasil 1999), as:

(...) the processes through which the individual and the community construct social values, knowledge, abilities, attitudes and competences aimed at the conservation of the environment (...) .

But how to achieve such an objective?

\subsection{Environmental Education}

EE has been the subject of discussions since 1965, when the term was coined during the "Education Conference" held in Keele in Great Britain. It emerges as an effort for change, before the great repercussion of serious environmental problems that affected several regions of the world at that time (Possas \& Gemaques 2002). By that time, EE was understood as a transformative tool, essential for tackling environmental issues, favoring individual awareness of the responsibilities towards the environment (Barbieri 2002).

Although it has been debated for some time now, EE has had global expression only after the Conference on the Human Environment, held in Stockholm in 1972 (United Nations 1972). The Tbilisi Declaration, fruit of the Intergovernmental Conference on Environmental Education held in Tbilisi in 1977, stated that EE should enable the individual to understand the main problems of the contemporary world, providing them with the technical knowledge and the qualities necessary to perform a productive function aiming at improving life and protecting the environment, attending to ethical values.

From these great meetings, various treaties, laws and guidelines were drawn up to define and govern the theme throughout the world. In Brazil, the National Curricular Guidelines for Environmental Education, in Article 2, define EE as:

(...) a dimension of education, an intentional activity of social practice, which should impress upon individual development a social character in its relationship with nature and with other human beings, in order to empower this human activity with the purpose of making it fulfill social objectives and environmental ethics. (Brazil 2012). 
The main objective of EE is to create a collective conscience in order to contribute to the improvement of every being's quality of life, as well as the relationships established between these individuals and the environment. Furthermore, through citizenship and a sense of belonging, it is assumed that $\mathrm{EE}$ can contribute to the achievement of a society that is aware of its responsibility towards the environment and to the search for solutions to environmental problems (Sorrentino et al. 2005). For Cuba (2010, p. 28) "Environmental Education is a strategy to achieve the desired changes in current education".

It is important to emphasize that this aspect of education goes far beyond "preserving the environment and its resources", it is essentially based on relations with the environment. One must therefore consider the innumerable singularities of relations and systems existing on our planet (Sauvé 2005). Thus, it is fundamental to understand these interactions. This author also proposes some relationships with the environment that should be considered in the educational process. They are: natural environment / nature, resource environment, problem environment, system environment, environment in which one lives, biosphere environment, community environment.

Gonzalez-Gaudiano (2005) points out that formal education still develops within the dictates of conventional disciplines, and interdisciplinarity continues to have a character of possibility, since it does not yet have an adequate definition within the limitations of the school curriculum. However, as stated in Article 8 of the National Curricular Guidelines for Environmental Education (Brasil 2012), due to the interdisciplinary nature advocated, EE should not be approached in the form of a discipline or as a specific curricular component, but rather in a cross-sectional and continuous form, during all phases of formal education (Brazil 2012). Thus, interdisciplinarity emerges as an attempt to reorganize knowledge, aiming to promote a better understanding of the environment and society (Gonzalez-Gaudiano 2005).

The Tbilisi Declaration also points out that the global and interdisciplinary perspective, upon which EE is based, provides an overview of the environment, where the intrinsic interdependence between natural and artificial environments is recognized (UNESCO 1977). Thus, since this field of education is not limited to any discipline, but is based on the multiple interactions between them, it is clear that interdisciplinarity, although little understood and realized, represents the best path (Gonzalez-Gaudiano 2005).

\subsection{Systemic Theory and Earth System Sciences}

The General System Theory, known as Object Modeling Theory, contains Ludwig von Bertalanffy's conception, which considers "General System: The system is a model of a general nature" (Le Moigne 1996)

After being studied for several years, although without much publicity, the theory came to be included in several scientific branches, among them, the scientific branch of Physical Geography, which appropriates this concept for adapting itself to the principles of interdisciplinarity, synthesis, multi-scale approach and dynamics of landscapes (Rodrigues 2001).

Similarly, there was an expansion in the field of study of Geosciences beyond the earth's crust, in order to re-signify environmental impacts and natural disasters. Since then, the study of processes that involve different terrestrial spheres have been integrated through consecutive interrelationships of the events that occurred throughout the planet (Carneiro et al. 2005, Piranha 2006).

With the worsening of the environmental crisis and the concern with the theme, some studies brought together classic concepts of Environmental Sciences with those of Geology, to deal with Terrestrial Systems (Carneiro et al. 2005). Therefore, the study of Earth System Science arose, which "expresses itself in a systemic way, integrates the different spheres in which matter is organized and in which all forms of energy are equivalent and can be exchanged" (Piranha 2006, p.2).

Huggett (2007) states that in a more modern approach, the elements of a system interact intensely in complex, organized and dynamic ways. Such interaction is easily observed in biological ecosystems, but is by no means restricted to them (Huggett 2007). Zerfass \& Angels-Zerfass (2016) also point out that the constituents of the system are as important as the interactions established between them, so that such relations should not be fragmented, neither analyzed separately, because in this case systemic identity is lost.

One subject touched by Earth Sciences is the depth of geological time and the greatness/scales/ proportions of the universe. To understand this dimension of time is to realize that the existence of

\begin{tabular}{c|c|c|c|c|c}
\hline (C) Terrae Didat. & Campinas, SP & v.14 & n.4 & p. 363-368 & out./dez. 2018 \\
\hline
\end{tabular}


humanity is limited to an ephemeral portion of planetary history (Bonito et al. 2011). With the understanding of the temporal scale, the environmental transformations are more easily dimensioned and it is possible to perceive the speed with which the environment is being (re)organized. In this way, it is possible to develop a "culture of intervention [...] aimed at the development of a more conscious citizenship" (Bonito et al. 2011, p. 83).

The understanding of Earth System Sciences enables the recognition of the effects caused by human actions on the planet, which allows the emergence of awareness concerning the role of man regarding the environment.

\subsection{Permaculture}

With the advance of modern agriculture, monoculture on a large scale has become a recurring practice because it is more profitable. The simplification of agriculture together with the excessive use of inputs, intensive land use and destruction of ecosystems shows signs of collapse. Studies of human societies at various times in history, which remained for long periods in one place without their environment being destroyed, led Bill Mollison and David Holmgre to coin the term Permaculture, in 1978, which is derived from the words "Permanent" and "Agriculture". The expression thus means "Permanent Agriculture" (Holmgren 2013).

Permaculture studies emerged initially as an effort to change the environmental reality, the way agriculture is done, and to meet the needs of families, communities and even small towns. It refers to an agricultural ecosystem constructed from the integral modeling of the system, aiming at integrating the various constituents of the environment in a harmonious and lasting way, so that the system becomes almost self-sufficient (Mollison \& Holmgren 1981, Holmgren 2013). Holmgren (2013, p. 33 ) defines it more succinctly, "more precisely, I see permaculture as the application of systemic thinking and design principles that serve as the basis for the implementation of the enunciated vision."

Diversity is essential in this model. According to Mollison (1981), diversity goes beyond the number of elements of a system, it is the number of functional connections between these elements. It therefore seeks to establish as many connections as possible in order to make the system more complex and consequently more stable and permanent.
For Mollison \& Holmgren (1981) this model gains impact as the problem of world hunger and resource and energy shortages worsen, in face of environmental devastation. The effects of inconsequential use of resources and inattention to future generations are already perceived. Odum \& Odum (2012, p. 14) point out that "every year more effort is needed to provide the fuel, water, wood, fish, soil, food, electricity and minerals from which spins all the rest ".

The term "permanent agriculture" later evolved to "permanent culture", because according to Mollison \& Slay (1994), no culture resists without a solid and sustainable agriculture. In this context, people, their way of life and their homes are integral and fundamental parts (Holmgren 2013). In addition, the concept and its foundations are broad and not limited to agriculture, much less to rural areas. Permaculture can be developed and have its principles inserted into the daily life of big cities. According to Mollison \& Holmgren (1981), perhaps the most important result for a city that practices permaculture would be peace of mind, since feelings of impotence in relation to current and future environmental crises would be reduced.

According to Holmgren (2013), the multifaceted nature of Permaculture enables its evolution, allowing the expansion of "alternative solutions" for the benefit of the environment. In this context, permaculture began to be developed in a broad perspective, in the construction industry, through bio-construction and bioarchitecture, in the reuse of residues, in reading the landscape / spirit of the place, in participatory art and music, in holistic medicine, in ethical investment, in conflict reduction, in cohabitation cooperatives, in organic and biodynamic agriculture and agroforestry, among others (Holmgren 2013).

Permaculture is also based on ethical principles that govern its ideology. They are: caring for the Earth, which advocates taking care of all things, alive or not, from the ground to entire ecosystems. Caring for people refers to meeting the basic needs of the entire population, such as food, shelter, education, health and work. In order to achieve the goal of caring for the Earth and people, it is of the utmost importance to donate surplus production, energy and time (Mollison \& Slay 1994, p. 15). Finally, the principle of the ethics of life is based on "recognizing the intrinsic value of everything that lives" and recognizing that "a tree is something of 
value in itself, even if it has no commercial value to us" (Mollison and Slay, 1994, page 15).

In this way, as mentioned above, permaculture is not based exclusively on agriculture, but on a series of principles that seek to create a new way of being and thinking, involving "aspects of environmental, community, economic and social systems" (Mollison \& Slay 1994, p. 15). Based on the ecological principles, interrelationships and interdependence between the constituents of a system, whether locally or globally, it allows the reconnection of man with the environment, developing a sense of belonging and care for the environment, favoring transforming attitudes towards the environment, besides motivating the exercise of citizenship (Morrow 2010). Thus, it is clear that this concept can favor the educational process, since it advocates a systemic and interdisciplinary vision for development, as well as promoting care for others. Still on education, Mollison \& Holgren (1981, p. 108) state that:

Educational inferences are also obvious, since students of any age can build and observe a permacultural ecosystem, and in doing so, develop technical skills for out-of-school use and devise methods of using garbage while practicing the science of ecology. Almost any discipline can find an application in a permacultural ecosystem.

To the extent that permaculture awakens less anthropocentric conceptions of science and environment, valuing relationships and the perception of biodiversity and its importance, it can contribute to a society with common ideas and objectives of preservation, and to the "evolution of a truly ecological science in education and living" (Mollison \& Holmgren 1981, p. 16).

\section{A Reforming the Thinking and Organization of Knowledge}

Faced with the urgency for change resulting from the chaotic reality of the world, education and especially EE gives rise to hope. However, the need for reforming the way of thinking and practicing education is undeniable, so that it can effectively be a transformative tool.

This is still a challenge, since many gaps exist, from initial training to the training of environmental educators. The difficulty of includingin contents in a theoretical-practical way ends up hampering the teaching-learning process. According to Guerra \& Guimaraes (2007, p. 165), it is up to the educator to seek resources and theoretical references that contribute to a new perspective, enabling a critical-reflexive vision based on the principles of EE, so that:

[...] together, in a joint-collective movement of praxis, of theory and practice, action and reflection, create possibilities of differentiated practices of a critical Environmental Education, which we believe capable of contributing to the transformation of the socio-environmental reality, and which affects all educational environments, including University and School, in a vital relationship of reciprocity.

In this sense, Morin (2003) states that "An intelligence incapable of perceiving the context and the planetary complexity becomes blind, unconscious and irresponsible" (Morin 2003, p. 14). Therefore, it is important to note the fundamental role of Earth System Sciences, since it allows the understanding of the complex and inseparable interrelationship between the elements of a system, or several systems (Piranha et al. 2011). This theoretical framework contributes to EE since it stimulates critical reflection on our role and the consequences of our actions in the various spheres of the environment. This contributes to the reconnection of man to the environment, a fundamental aspect for the effectiveness of EE.

In the same way, studies about permaculture also invite humans to become an integral part of environment, in addition to valuing the respect for different constituents. Thus, permaculture spaces can function as large interdisciplinary outdoor laboratories, enabling the development of activities outside the classroom, which, according to Marques \& Praia (2009, p. 18) contribute to:

Answer questions concerning the understanding of natural systems in their complexity, as the object of study is indeed understood in its own context.

Therefore, we can conclude that both the theoretical precepts of Earth System Sciences and Permaculture favor the emergence of a paradigm shift. The articulation of this knowledge enables a broad and contextualized understanding of the environment: while Earth System Sciences allow the understan- 
ding of the environment and its interdependencies, Permaculture teaches us how we can live in balance with the environment. Therefore, such precepts, understood in the light of complex thinking, can contribute essentially to a more critical, reflexive and human EE, consequently enabling the development of a society which is more connected to Earth.

\section{Acknowledgments}

We express our gratefulness for the careful revision of the reviewers, in order to improve the quality of this article.

\section{References}

Brazil. 1999. Lei $n^{\circ} 9.795$. Dispõe sobre a educação ambiental, institui a Politica Nacional de Educação Ambiental e dá outras providencias. 27.Apr.1999. Brasília.

Brazil. Ministério da Educação. Conselho Nacional de Educação. Conselho Pleno. 2012. Resolução no 2, estabelece as Diretrizes Curriculares Nacionais para a Educação Ambiental, 15 de Jun. de 2012. Brasília.

Barbieri J.C. 2002. Introdução. In: Brasil. Ministério da Educação. Secretaria de Educação Fundamental. Coordenação Geral de educação Ambiental. Educação Ambiental Legal. Brasília, MEC.

Bonito J., Rebelo D., Morgado M., Monteiro G., Medina J., Marques L., Martins L. 2011. A complexidade do tempo geológico e a sua aprendizagem com alunos portugueses (12-13 anos). Terre Didatica, 7(2):81-92.

Capra F. 1996. A teia da vida. Uma nova Compreensão Científica dos Sistemas Vivos. São Paulo, Ed. Cultrix.

Carneiro C.D.R., Gonçalves P.W., Negrão O.B.M., Cunha C.A.L. 2005. Ciência do Sistema Terra e o Entendimento da Máquina Planetária em que Vivemos. Belo Horizonte, Geonomos, 13(1):11-18.

United Nations (UN). (United Nations Declaration on Humanity, Stockholm, 1972). (United Nations Conference on the Human Environment).

Compiani M. 2010. Formación de Profesores, Profesionales Críticos, en la Enseñanza de Geociencias Frente a los Problemas Socio-Ambientales. Enseñanza de las Ciencias de la Tierra, 10(2):162-172.

Cuba M.A. 2010. Educação Ambiental nas Escolas. ECCOM, 1(2):23-31.

Guerra A.F.S., Guimarães M. 2007. Educação Ambiental no Contexto Escolas: Questões levantadas no GDP. Pesquisa em Educação Ambiental, 2(1):155-166.

González-Gaudiano E. 2005. Interdisciplinaridade e educação ambiental: explorando novos territórios epistêmicos. In: Sato M., Carvalho I. orgs. 2005. Educação ambiental: pesquisa e desafios. Porto Alegre:
Artmed. p. 119-133.

Holmgren D. 2013.Permacultura: Princípios e caminhos além da sustenrabilidade. Porto Alegre: Via Sapiens.

Huggett R. 2007. A history of the systems approach in geomorphology. Géomorphologie: relief, processus, environnement, 13(2):145-158.

Le Moigne J.L. 1977. A teoria do sistema geral: Teoria da modelização. Ed. Instituto Piaget.

Morrow R. 2010. Permacultura Passo a Passo. Pirenópolis, GO, Ed. Mais Calango. 238 p.

Mollison B. 198. Introdução à Permacultura: panfleto I da série "curso de design em permacultura". Yankee permaculture.

Mollison B., Holmgren D. 1981. Permacultura um - Uma Agricultura Permanente nas comunidades em Geral. Ed. Ground.

Mollison B., Slay R.M. 1994. Introdution to Permaculture. 2 ed. Austrália: A Tagari Publ.

Odum H.T., Odum E.C. 2012. O declínio próspero: princípios e políticas. Tradução de Ortega, E. Petrópilis, RJ: Vozes.

Piranha J.M. 2006. O Ensino de Geologia como instrumento formador de uma cultura de sustentabilidade: o Projeto Geo-Escola em São José Do Rio Preto, SP. Campinas, SP. (Tese Dout.)

Piranha J.M., Marques L., Prais J., Chaves I.S. 2011. Contributos do Pensamento de Edgar Morin para o ensino de Ciência do Sistema Terra numa abordagem complexa. Conferencia Iberoamericana de Complejidad, Informática e Cibernética: CICIC 2011. Orlando, Florida, EUA. Available in: <http:/www. iiis.org/cds2011/cd2011imc/cicic_2011/paperspdf/ cb708ny.pdf>. Aces.: 10/10/2017.

Possas A.R.O.C., Gemaque I.S.F.C. 2002. História da defesa do meio ambiente. In: CHAGAS M. A. (org.). Sustentabilidade e Gestão Ambiental no Amapá: Saberes Tucujus. Macapá: SEMA.

Ratto C.G., Henning P.C., Andreola, B. A. 2017. Educação Ambiental e suas Urgências: a constituição de uma ética planetária. Educação \& Realidade, Porto Alegre, 42(3):1019-1034

Reigota M., Prado B.H. 2008. Educação Ambiental: utopia e práxis. São Paulo: Cortez.

Rodrigues C. 2001. A Teoria Geossistêmica e sua contribuição aos estudos geográficos e ambientais. Revista do Departamento de Geografia, 14.

Sato M., Carvalho I.C.M. 2005. Educação Ambiental: Pesquisa e Desafios. Porto Alegre: Artmed.

Sauvé L. 2005. Educação Ambiental: possibilidades e limitações. Educação e Pesquisa, São Paulo, 31(2):317322.

Sorrentino M., Trajber R., Mendonça P., Ferraro-Junior L.A. 2005. Educação Ambiental como políticas públicas. Educação e Pesquisa, São Paulo, 31(2):285299.

Declaração de Tbilisi. Paris: UNESCO.

Zerfass H., Anjos-Zerfass G.S. 2016. A sedimentação em uma abordagem sistêmica. Terrce Didatica, 12(2):126-149. 